\title{
The Effect of Adding Natural Detoxifying Such as Dried Blueberries or Wheat Bran or Nano-Charcoal to Biscuits on Rats Infected with Aflatoxin Shalaby, M. T.; A. I. Abdel-Gawwad; Amalika D. El-Dahshan and Heba E. Amin Food Industries Dept., Fac. of Agric., Mansoura Univ., Egypt
}

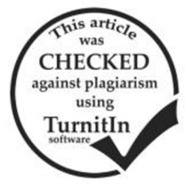

\section{ABSTRACT}

Consumption of aflatoxin contaminated food are dangerous source to human health because of their toxic, carcinogenic, hepatotoxic and mutagenic characteristics. Due to their harmful effects concerned on bring up todate the detoxification methods applied for reduction of aflatoxins by physical (adsorption), chemical (chemical compound) methods. The present study aimed to investigate the influence of some natural additives in biscuit such as dried blueberries, wheat bran and nano-charcoal as detoxifying agents which are available and inexpensive, that would modulate aflatoxin metabolism to reduce aflatoxins contamination, which enhances food safety and human health.Thirty adult male albino rats were partitioned into five groups. The first main group ( $\mathrm{n}=6$ rats), negative control, was fed on basal diet. The second group was fed on peanut diet contaminated with $20 \mathrm{ppb}$ aflatoxin / gram (ng/g diet), positive control, ( AFL+diet). Groups from group three to five were fed toxic diet + detoxifying agent (biscuit addition of dried blueberries or wheat bran and nano-charcoal, respectively) for 8 weeks. The results revealed the adverse impacts of aflatoxin contaminated diets on hematological alterations, lipid profile, liver functions, serum protein parameters, kidney function and hepatic and kidney histological.The lipid profile (TC, TG, HDL and LDL) were improved in treated groups compared with positive group G2. Addition of dried blueberries or wheat bran and nano-charcoal to biscuit significantly $(\mathrm{P}<0.05)$ enhanced liver functions, also serum protein parameters (albumin, globulin and total protein) and kidney function ( creatine and urea) in which obtained results were nearly the same of negative group (G-ve) . But, groups exposure to aflatoxin increased the level of cholesterol, triglycerides, LDL, HDL, creatine and urea.Hence, it could be finished that efficient use of dried blueberries or,wheat bran and nano-charcoal to biscuit as food additives against the toxicity of aflatoxin may lead to decrease their the harmful effects.

\section{INTRODUCTION}

The most important mycotoxins , e.g., aflatoxins which are produced by some of fungus in foods such as peanuts, maize, grains and cereals through developing world (Kamkar et al., 2013 and Wacoo et al. , 2014 ). Aflatoxins are carcinogenic and toxic mycotoxins produced by Aspergillus spp. They are classified as group 1carcinogens by (the International Agency for Research on Cancer) (IARC) (Ostry et al., 2017). The contamination of food with mycotoxins is a significant problem for the adverse effects on animals, humans and crops that result in sickness and economic losses (Reddy et al., 2009). For this reason, a number of methods have been studied related with their effectiveness to control of aflatoxin in food and feedstuffs contaminated with toxin (Di Stefano et al., 2014).

Detoxification effects on mycotoxin-containing food and feedstuffs included physical procedures by mycotoxin binders in human intervention (Jans et al. 2014) or chemical approaches (Jouany, 2007). A practical approach for the detoxification aflatoxins as adsorbents have the potential to bind aflatoxin and prevent their absorption from gastrointestinal (Kannewischer et al., 2006).

Absorbent compound approach to decrease the risk of mycotoxicosis in farm animals and to reduce the carryover of mycotoxins (especial aflatoxin) from contaminated feeds into food of animal origin (Hasheminya and Dehghannya, 2013). The mycotoxin-sequestering capacity of activated charcoal depends on the specific surface area which is different in lignin-based and in activated charcoal (Ramos et al., 1996).

Nano-charcoal is an excellent adsorbent, and it has been widely used in, e.g feed additive, food processing, nutrition, medicines and cosmetics (Kittinaovarat and Suthamnoi, 2009). The unique composition of nanocharcoal are reducing the toxic effects of aflatoxin contamination (Shabani et al., 2010). A novel nanoadditives of charcoal is studied to reduce the size of the adsorbents and their quantity duo to they may change the matters organoleptic and nutritional values of foodstuff (Madrigal-Santillan et al., 2010).
Whole grains, bran brown rice, provide important detoxification enhancing substances such as fibre binds to toxins and decreases transit time an excellent source of dietary fiber to assist with detoxification. Because of mycotoxin concentrations in surface tissues of (grains, sorting, cleaning, dehulling and debranning) reduce mycotoxin contamination of the flour. A large fraction of mycotoxins can be destroyed with damaged kernels, fine material and dust (Cheli et al., 2013). Rice bran is therapeutic for detoxification for different reasons such as liver function as they assist in reduce inflammation and the healthy processing of fats.

Berries have the diversity and high concentration of antioxidants that dependent on the species and cultivar considered. Preharvest practices, environmental conditions, maturity at harvest, postharvest storage and processing operations are urgent determinants of the phytochemical profiles (Jimenez-Garcia et al., 2012) .Natural substances that can prevent aflatoxin toxicity would be helpful to human and animal health with minimal cost in foods and feed. Traditional medicinal plants were used by some authors for their antifungal, anti-aflatoxigenic and antioxidant activity (Kumar et al., 2007). Carotenoids (carotenes and xanthophylls) found in fruits eg lutein and lycopene , carotene, $\beta$-cryptoxanthin, neoxanthin, , 5,6-epoxylutein cisand zeaxanthin and trans-violaxanthin have also been recognized in berries fruits (Szajdek and Borowska,2008 and Lashmanova et al., 2012) .

Chemoprevention has been intended as good strategy to decrease losses because of aflatoxin contamination in feed. Natural antioxidants : vitamins $\mathrm{E}$ and $\mathrm{C}$, selenium, carotenoids, L-carnitine and melatonin were added for preventing mycotoxins because their effect on provoke oxygen free radical formation and the ability of these compounds to act as superoxide an ion scavengers (Guarisco et al., 2007 and Pál et al., 2009) .

This study was investigated the effect of addition of some natural additives to biscuit such as dried berries or wheat bran and nano-charcoal on toxicity in rats fed diets contaminated with aflatoxins . 


\section{MATERIALS AND METHODS}

Materials:

Natural additives:_Blueberries, wheat bran and charcoal were purchased from local market of Mansoura city - ElDakahlia Governorate.

Raw material: Peanut, Flour, Corn, Sugar , Salt, Egg , Vanilla and Baking powder from local market in Mansoura city -El-Dakahlia Governorate.

Experimental:

Preparation of nano-activated charcoal:

Samples were grinded then powdered and sieved through spheres of stainless steel balls were used as grinding media as (Amir et al., 2010).

\section{Characterization of nano-activated charcoal}

Size, surface area, shape, crystal structure and morphological data of the found nanoparticles were characterized using transmission electron microscopy, TEM (JEOLTEM-2100) connected to a CCD camera at an accelerating voltage of $200 \mathrm{KV}$.

TEM measurements were recorded at the Central Laboratory, Electron Microscope Unit, Faculty of Agriculture, Mansoura University, Egypt.

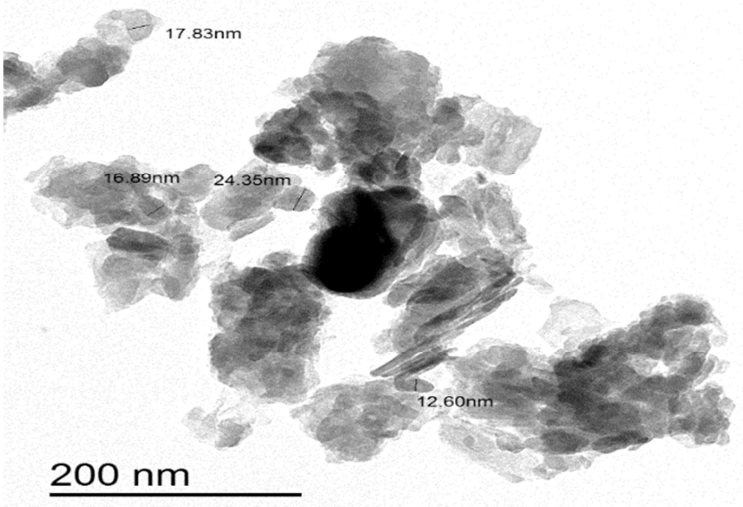

Figure 1. Transmission electron microscope photographs of prepared activated carbon

Preparation of biscuits:

The ingredients for control biscuits were: wheat flour $270 \mathrm{~g}$; corn $135 \mathrm{~g}$ butter $100 \mathrm{~g}$; powdered sugar $140 \mathrm{~g}$; salt $0.5 \mathrm{~g}$; vanilla $0.5 \mathrm{~g}$; 1 egg and baking powder $1 \mathrm{~g}$.

In other samples certain amount of the main raw material (wheat flour) was diminished on account of dried blueberries or wheat bran or nano-charcoal to obtain enriched biscuits. Namely, wheat flour was replaced by 60 gram dried blueberries or 15 gram wheat bran or 1 gram nano-charcoal. Dough was prepared by mixing all the ingredients, rolled out and shaped as round biscuits. The biscuits were baked in oven for 12 minutes at $180^{\circ} \mathrm{C}$. After cooling, the biscuits were packaged into plastic bags and than stored at room temperature.

Experimental animals:

The experimental thirty male albino adult rats were obtained from Nicer Nile Academy of the Research, Mansoura, Egypt.

Experimental design:

Body weight of rats ranged from $160 \pm 10$ gram. A number of 30 rats were divided into 5 groups each contained 6 rats, were kept under normal healthy conditions.
Rat in each group was housed individually into separate stainless steel box in a room at temperature of $26^{\circ} \mathrm{C}$. Water was admitted freely to rats from glass bottles mounted.

Then, rats of G1 to G5 were fed as follows:

G1(G-ve): Rats fed on basal diet (Commercial pelleted diet ) (from Ain 93, Modern Vet. Lab., contained 21\% crude protein, $3 \mid \%$ crude fat, less than $5 \%$ crude fiber, and $3190 \mathrm{Kcal} / \mathrm{Kg}$ ) (BD). Was used also for feeding all rats for 6 days as acclimatization period.

G2(G+ve): Rats fed on toxic diet (Positive control)( peanut natural contaminated with toxin at the level of $20 \mathrm{ppb}$ total aflatoxin (ng/g diet))

G3: Rats fed on $50 \%$ toxic diet (peanut natural contaminated with aflatoxin) $+50 \%$ biscuit with dried blueberries

G4: Rats fed on $50 \%$ toxic diet (peanut natural contaminated with aflatoxin) $+50 \%$ biscuit with wheat bran

G5: Rats fed on $50 \%$ toxic diet (peanut natural contaminated with aflatoxin) $+50 \%$ biscuit with nano-charcoal

An amount of food equal to 100 gram was weighed and hired in the dish inside the box. This was allowed for utilization over the day.

Animals were weighted once a week and the weights of the animal were recorded to follow their growth. The animal experiment lasted after 8 weeks.

\section{Biochemical Analysis:}

After 8 weeks (at the end of experiment), rats were fasted overnight, blood samples were taken from three rats of each group. Blood samples were taken immediately after the slaughter of rats, to study the influence of aflatoxin on some blood parameters.

White blood cells count (WBCs), red blood cell count (RBCs) and hemoglobin concentration $(\mathrm{Hb})$ were measured according to Cynthia et al., (1993)

Included blood plasma concentrations of glucose, total protein (TP), albumin, triglycerides (AL) and total cholesterol (TC) as well as activity of transaminases [alanine aminotransferase (ALT) and aspartate aminotransferase (AST)] in blood plasma were determined Three blood samples per treatment were obtained during slaughtering and kept in heparinized test tubes. They were immediately centrifuged at 3000 r.p.m for 15 minutes to separate blood plasma, which was frozen at $-20^{\circ} \mathrm{C}$ until later study.

Serum liver enzymes including aspartat aminotransaminase (AST), alanine aminotransaminase (ALT) and alkaline phosphatase (ALP) were determined according to (Reitman and Frankel, 1957 and Bowers and McComb, 1966). Serum total protein(TP), albumin(AL) ,globulin (GL), urea and creatinine were estimated according to( Doumas et al. (1981); Weissman et al., 1950; Kaplan and Tang , 1982 and Bartles et al., 1972 , respectively). Triglycerides(TG) ,Total Cholesterol(TC), HDL-c , LDL-c and Glucose were determined by (Tietz(1986) ; Fossati and Prencipe (1982) : Lopez ,1977 and Teuscher and Richterich, 1971), respectively.

\section{Histological examination:}

Rats fed on treated food and their controls were slaughtered, quickly anatomized and their kidney, liver are removed, sliced and fixed in 10\% formalin suspension.

After three days, tissues were cleansed three times in $70 \%$ ethanol, dehydrated using a graded ethanol series and then inserted in paraffin wax. Paraffin sections were cut into (5-6) micrometers thick slices, stained with 
(haematoxylin and eosin) scanned under light microscope (Drury et al., 1976).

Statistical Analysis

Data were subjected to statistical analysis using, one way classification, least significant differences (LSD) were determined at $\mathrm{P}$ value of $<0.05$ level according to SAS, (2006).

\section{RESULTS AND DISSCUSION}

Data of addition of dried blueberries or wheat bran or nano-charcoal to biscuit on hematological parameters : hemoglobin, red blood cells, hematocrit and white blood cells of toxicated rats fed aflatoxins contaminated diets are shown in Table( 1$)$. Hemoglobin $(\mathrm{Hb})$ content showed significant reduction in $(\mathrm{G} 2+\mathrm{ve})$ compared with control group (G1-ve). But, $\mathrm{Hb}$ showed significant increase in other groups $(\mathrm{p}<0.05)$.

Red blood cells (RBCS) count significantly decreased in G3 (6.31), G 4 (5.97) and G 5 (5.90) in comparing with (G1-ve). (6.52) $(\mathrm{p}<0.05)$. Also, positive group (G2+ve) showed significant decrease in RBCS in comparing with (G1-ve). Hematocrit (Hct) showed significant reduction in G3 (40.29), G4 (39.60) and G5 (39.57) compared with (G1-ve). (40.31).

Table1. Effect of biscuits with dried blueberries or wheat bran or nano- charcoal as detoxifying agents on hematological of toxicated rats with aflatoxin

\begin{tabular}{|c|c|c|c|c|c|c|}
\hline Parameters & G1 & G2 & G3 & G4 & G5 & SEM \\
\hline $\mathrm{Hb}(\mathrm{mg} / \mathrm{dl})$ & $13.77^{\mathrm{a}}$ & $12.47^{\mathrm{d}}$ & $13.32^{b}$ & $13.07^{\mathrm{c}}$ & $13.01^{\mathrm{c}}$ & 0.031 \\
\hline $\operatorname{RBCs}\left(\times 10^{6} / \mathrm{mm}^{3}\right)$ & $6.52^{\mathrm{a}}$ & $5.85^{\mathrm{c}}$ & $6.31^{\mathrm{b}}$ & $5.97^{\mathrm{c}}$ & $5.90^{\mathrm{c}}$ & 0.038 \\
\hline WBCs $\left(\times 10^{3} / \mathrm{mm}^{3}\right)$ & $8.58^{\mathrm{b}}$ & $8.95^{\mathrm{a}}$ & $8.43^{c}$ & $8.29^{\mathrm{d}}$ & $8.24^{\mathrm{d}}$ & 0.023 \\
\hline Hct $(\%)$ & 40.31 & 41.13 & 40.29 & 39.60 & 39.57 & 1.167 \\
\hline $\operatorname{MCV}(\mu 3)$ & 70.85 & 72.24 & 72.33 & 71.03 & 72.15 & 2.120 \\
\hline $\mathrm{MCH}(\mathrm{pg})$ & 20.45 & 21.31 & 21.15 & 21.82 & 21.33 & 0.717 \\
\hline $\operatorname{MCHC}(\mathrm{g} / \mathrm{dl})$ & 31.34 & 31.27 & 30.29 & 30.94 & 30.60 & 1.147 \\
\hline $\mathrm{MCV} / \mathrm{RBC}$ & $10.86^{\mathrm{b}}$ & $12.35^{\mathrm{a}}$ & $11.46^{\mathrm{ab}}$ & $11.90^{\mathrm{ab}}$ & $12.22^{\mathrm{a}}$ & 0.362 \\
\hline
\end{tabular}

Data are stated as means $\pm(\mathrm{SE})$.

Data at the same row with different letters are significantly different at $\mathrm{P}<0.05$

Regarding white blood cells (WBC) count, there was significant increase in (G2+ve) (8.95) compared with (G1-ve) (8.58) $(\mathrm{p}<0.05)$ and this elevation was significantly attenuated by using biscuit with berries in $G$ 3. So, this treatment recovered back the hemoglobin content, RBC and WBC cell count near to normal values.

Mahmoud et al. (1994) indicated that feeding animals contaminated food with mycotoxin influences their blood picture. On the other hands, The improvement happened in the results may be ascribed to berries fruits contents of antioxidants such as carotenoids and phenolic compound, vitamins and minerals which can prevent mycotoxins due to their effect on provoke oxygen free radical formation and act as superoxide an ion scavengers as represented by Szajdek and Borowska, 2008; Pál et al., 2009 and Lashmanova et al., 2012.

Table (2). Showed that several biochemical parameters are affected by aflatoxin exposure. Finally experimental, the positive group $(\mathrm{G} 2+\mathrm{ve})$ fed on contaminated aflatoxin diet only without any additives achieved significantly $(\mathrm{P}<0.05)$ reduction in serum total protein, albumin and globulin by $(23.48,26$ and 35.82\%) compared with the control group (G1-ve). Reduction in serum globulin in toxic fed group might be due to the adverse effect of aflatoxin B1 on combination of total proteins and globulin (Agag, 2004).

However, the experimental groups of rats fed biscuit with dried blueberries or wheat bran or nanocharcoal showed that the reduction in plasma total protein, albumin and globulin concentration were descended for (G2+ve)by ( $9.11 \%, 3.7 \%$ and $13.43 \%$ for group (G3) , $12.9 \%, 0.3 \%$ and $23.38 \%$ for group (G4) ,10.49,8.69 and 11.69 for group (G5), respectively, compared to negative group (G1-ve) ,such effect may be because of the metabolism of aflatoxins (in the liver )where it interferes with protein synthesis and RNA ,this resulted from the damage occured in liver by aflatoxins. There were significantly increased $(\mathrm{P}<0.05)$ in creatinine and urea in (G2+ve).

Data are in agreement with (Mogda, et al., 2015) who found that low total protein level acts as an indicator of the toxic effect of aflatoxin b1 in serum and creatinine and urea in positive group $(\mathrm{G} 2+\mathrm{ve})$ compared with control(G1-ve) because anhydride of creatinine, being formed when water is removed. Hence, plasma creatinine rises in renal disease.

Table 2. Effect of biscuits with dried blueberries or wheat bran or nano-charcoal as detoxifying agents on protein fractions (g/dl) and kidney functions $(\mathrm{mg} / \mathrm{dl})$ of toxicated rats with aflatoxins:

\begin{tabular}{|c|c|c|c|c|c|c|}
\hline Parameters & G1 & G2 & G3 & G4 & G5 & SEM \\
\hline Total proteins $(\mathrm{TP})(\mathrm{g} / \mathrm{dl})$ & $7.24^{\mathrm{a}}$ & $5.54^{\mathrm{d}}$ & $6.58^{\mathrm{b}}$ & $6.30^{\mathrm{c}}$ & $6.48^{\mathrm{b}}$ & 0.03 \\
\hline Albumin $(\mathrm{AL})(\mathrm{g} / \mathrm{dl})$ & $3.22^{\mathrm{a}}$ & $2.96^{\mathrm{c}}$ & $3.10^{\mathrm{b}}$ & $3.21^{\mathrm{a}}$ & $2.94^{\mathrm{c}}$ & 0.03 \\
\hline Globulin (GL) (g/dl) & $4.02^{\mathrm{a}}$ & $2.58^{\mathrm{d}}$ & $3.48^{\mathrm{b}}$ & $3.08^{\mathrm{c}}$ & $3.55^{\mathrm{b}}$ & 0.06 \\
\hline Albumin / Globulin ratio (A / G ratio) & $0.81^{\mathrm{c}}$ & $1.15^{\mathrm{a}}$ & $0.89^{\mathrm{c}}$ & $1.04^{\mathrm{b}}$ & $0.83^{\mathrm{c}}$ & 0.03 \\
\hline Creatinine $(\mathrm{mg} / \mathrm{dl})$ & $1.22^{\mathrm{d}}$ & $1.55^{\mathrm{a}}$ & $1.30^{\mathrm{c}}$ & $1.37^{\mathrm{b}}$ & $1.39^{\mathrm{b}}$ & 0.02 \\
\hline Urea (mg/dl) & $36.33^{b c}$ & $47.08^{\mathrm{a}}$ & $33.37^{\mathrm{c}}$ & $38.36^{\mathrm{bc}}$ & $42.70^{\mathrm{ab}}$ & 2.27 \\
\hline
\end{tabular}

Data are stated as means $\pm(\mathrm{SE})$.

Data at the same row with different letters are significantly different at $\mathbf{P}<0.05$ 
Total lipid, triglycerides and total cholesterol were determined in blood serum experimental rats to assess the effect of natural additives such as dried blueberries, wheat bran and nano-charcoal to biscuit on aflatoxin contaminated diets. The obtained data are given in Table (3). The level of total cholesterol (TC), total triglycerides (TG), LDL and HDL were significantly increased $(\mathrm{P}<0.05)$ in $(\mathrm{G} 2+\mathrm{ve})$.
Treated groups are shown decreased $(\mathrm{P}<0.05)$ in the mean level of total cholesterol (TC), triglycerides (TG), LDL and HDL parameters compared to ( G+ve). Data are in agreement with Stanely et al., (2004) who reported that there area significant decrease in serum total cholesterol.

Table 3. Effect of biscuits with dried blueberries or wheat bran or nano-charcoal as detoxifying agents on Lipid metabolism (mg/d) of toxicated rats with aflatoxins:

\begin{tabular}{lcccccc}
\hline Parameters & G1 & G2 & G3 & G4 & G5 & SEM \\
\hline Total Cholesterol (TC) ( mg/dl) & $96.33^{\mathrm{c}}$ & $132.55^{\mathrm{a}}$ & $110.77^{\mathrm{b}}$ & $108.33^{\mathrm{b}}$ & $105.67^{\mathrm{b}}$ & 2.09 \\
Total Triglycerides (TG) ( mg/dl) & $88.40^{\mathrm{b}}$ & $105.07^{\mathrm{a}}$ & $92.33^{\mathrm{b}}$ & $99.50^{\mathrm{ab}}$ & $96.83^{\mathrm{ab}}$ & 3.41 \\
LDL ( mg/dl) & $43.67^{\mathrm{b}}$ & $54.80^{\mathrm{a}}$ & $46.33^{\mathrm{b}}$ & $45.30^{\mathrm{b}}$ & $44.1^{\mathrm{b}}$ & 2.49 \\
HDL ( mg/dl) & $35.33^{\mathrm{a}}$ & $23.00^{\mathrm{c}}$ & $31.07 \mathrm{a}^{\mathrm{b}}$ & $28.73^{\mathrm{bc}}$ & $25.07^{\mathrm{c}}$ & 1.81 \\
\hline
\end{tabular}

Data are stated as means $\pm(\mathrm{SE})$.

Data at the same row with different letters are significantly different at $\mathrm{P}<0.05$

Aflatoxin has a harmful and stressful effect on liver. AST, ALT and ALP are cytosolic enzymes, famous biomarkers of liver damage and have been used as the biochemical indicators for hepatic damage. The results of the current study suggested that exposure to aflatoxin resulted in a significant increased $(\mathrm{P}<0.05)$ in AST and ALT level as compared with control group( G1-ve) as showed in (Table 4).

These results are in agreement with Sherif et al., (2009) who found that most increases in ALT activity are associated with hepatocellular damage, when cellular degeneration happenings in liver because liver cell death and liver injury. Moreover, treated groups fed on biscuit with wheat bran or nano-charcoal at the tested level significantly decreased $(\mathrm{P}<0.05)$ the elevated levels of serum ALTand AST compared to $(\mathrm{G} 2+\mathrm{ve})$. The best results of liver functions were documented for the group fed on biscuit with dried blueberries in group (G3).

Similar results have been reported by Sahin and Sehu, (2007) who showed that serum biochemical values (glucose, protein, $\mathrm{Ca}$ and $\mathrm{P}$ content) were reduced.

Table 4. Effect of biscuits with dried blueberries or wheat bran or nano-charcoal as detoxifying agents on liver function (IU/I) of toxicated rats with aflatoxins:

\begin{tabular}{lcccccc}
\hline Parameters & G1 & G2 & G3 & G4 & G5 & SEM \\
\hline AST (IU/1) & $44.25^{\mathrm{c}}$ & $59.51^{\mathrm{a}}$ & $45.25^{\mathrm{c}}$ & $48.03^{\mathrm{bc}}$ & $52.81^{\mathrm{b}}$ & 1.60 \\
ALT (IU/1) & $31.23^{\mathrm{d}}$ & $42.85^{\mathrm{a}}$ & $34.13^{\mathrm{dc}}$ & $37.21^{\mathrm{bc}}$ & $40.33^{\mathrm{ab}}$ & 1.15 \\
ALP (IU/1) & $80.75^{\mathrm{a}}$ & $70.61^{\mathrm{c}}$ & $77.50^{\mathrm{ab}}$ & $74.68^{\mathrm{bc}}$ & $71.10^{\mathrm{c}}$ & 1.66 \\
Glucose & $120.67^{\mathrm{a}}$ & $97.67^{\mathrm{c}}$ & $111.67^{\mathrm{ab}}$ & $106.07^{\mathrm{bc}}$ & $100.13^{\mathrm{bc}}$ & 3.58 \\
\hline
\end{tabular}

Data are stated as means \pm ( SE ).

Data at the same row with different letters are significantly different at $\mathbf{P}<0.05$

\section{Histopathological Investigations}

Liver:

Liver plays a great role in detoxification any injury to it or impairment of its functions may lead to many modulation on one's health (Subramaniam et al., 2015).

As shown in Fig.2 (A-B), the histopathological profile of the liver of control group (G1) showed the normal architecture of the classic hepatocytes. The hepatocytes from branching cords radiating from the central vein. Normally, they showed vesicular nuclei. The cells appeared to be separated by the blood sinusoids that arrangements by endothelial cells (Fig.2.A).

Treated group with aflatoxin contaminated diet(positive group) (G2+ve) showed degenerative changes in the hepatocytes .Cells all over the hepatic lobules were noted to have fat vacuoles( Fig.2.B). The most significant improvement in the histological structure was found in group G3 fed on biscuit enriched with dried blueberries (Fig.2.C) which showed normal designed structure of hepatic which was almost similar to that of (G-ve). (Fig.2.A).

Treated group with biscuit addition of wheat bran(G4) showed apparently normal hepatocytes. Also, they showed few mononuclear infiltrations and degenerated leukocytes. Moreover, normal appearing round nuclei is also noticed. It is illustrated in (Fig. 2.E) shows hepatic tissues of rats fed biscuits addition of nanocharcoal (G5) with no necrotic hepatic and nearly normal hepatic strands.

Similar results were shown by Abdelhamid (1995) who found that feeding animals food contaminated with mycotoxin caused pathological findings, particularly in heart, liver, kidney, and spleen.

The changes involve (hepatic round, cell infiltration, focal necrosis, irregularities of lobular plats and periportal fibrosis).

Berries consumption could invert most of the histological and biochemical changes in the liver of the group fed aflatoxin contaminated diets because its hypoglycemic and antioxidant effects. The histological investigation provide clear confirmation for hepatoprotective effect of berries in positive group which is in close agreement with the information presented by Mogda et al., (2015 ) who found that antioxidants typically boost the liver's health and can dismiss any excess damage done to the liver and may even hurry liver recovery. 


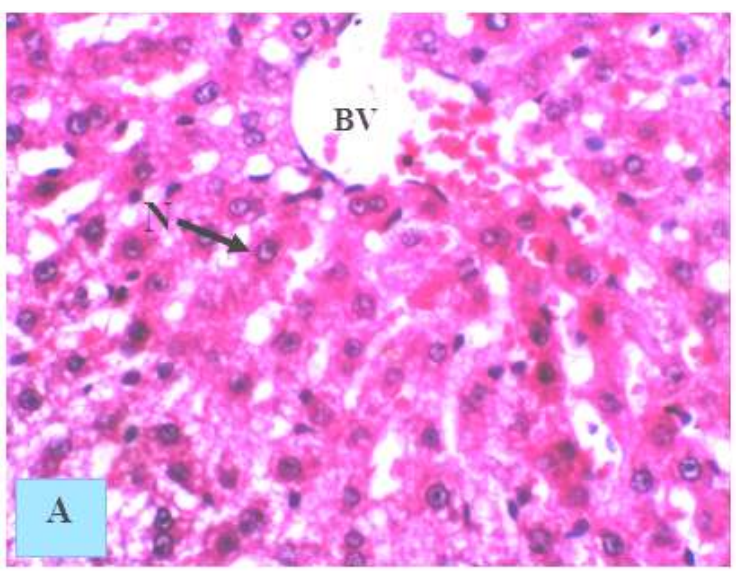

Fig. 2. A. Photomicrographs of histological section of control group (G1) of liver showing normal hepatocytes with normal nucleus and naturally hepatocyte arrangements with intact blood sinusoids. BV,Blood vessel ; N, nucleus. (H\&E. X400).

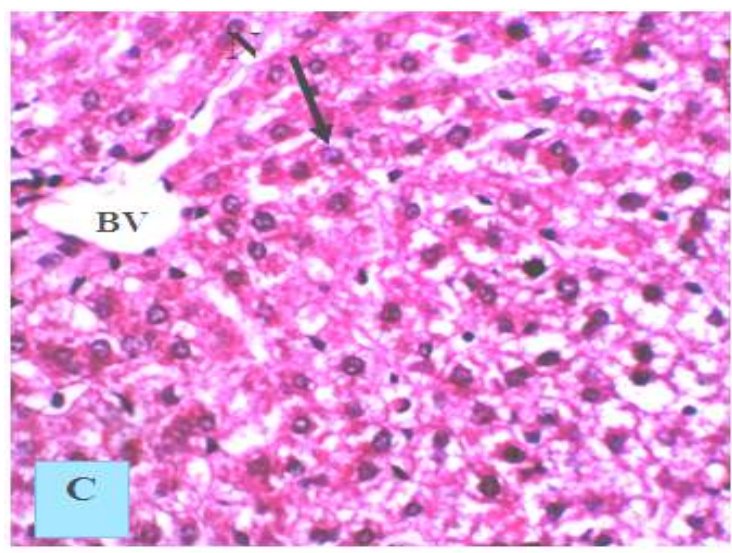

Fig. 2. C. Photomicrographs of histological section of liver group (G3) showing nearly normal hepatocyte arrangements with intact blood. (H\&E X400).

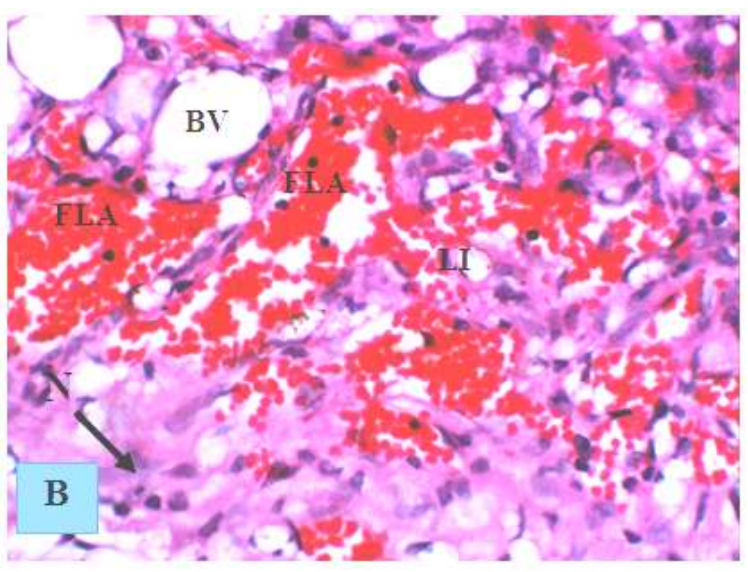

Fig. 2. B. Photomicrographs of histological section of liver of positive group (G2) showing increased leukocyte severe infiltration between hepatocytes and hepatocellular degenerated (abnormal nucleus) ,ballooning degeneration inflammation and loss of cellular boundaries. leukocy infiltration $(\mathrm{LI})$. Focal leukocyte aggregation (FLA), BV, Blood vessel; N,nucleas. (H\&E. X400).

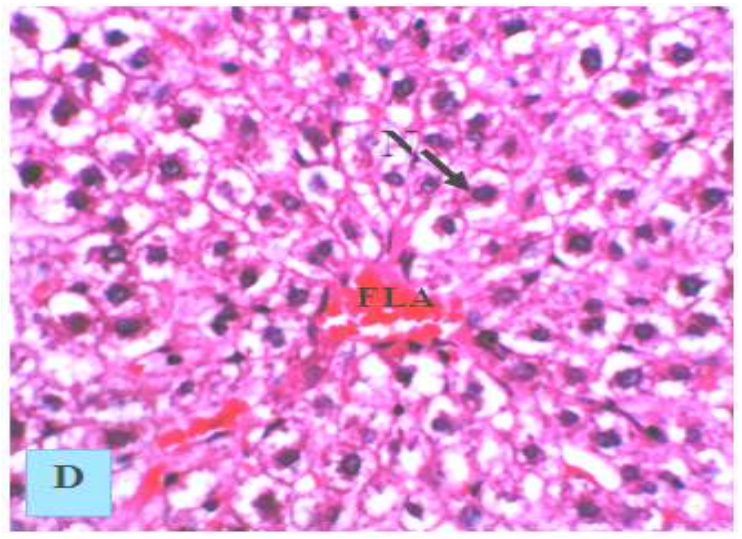

Fig. 2. D. Photomicrographs of histological section of liver group (G4) showing nearly hepatic cell but also degenerated leukocyte. (H\&E. X400).

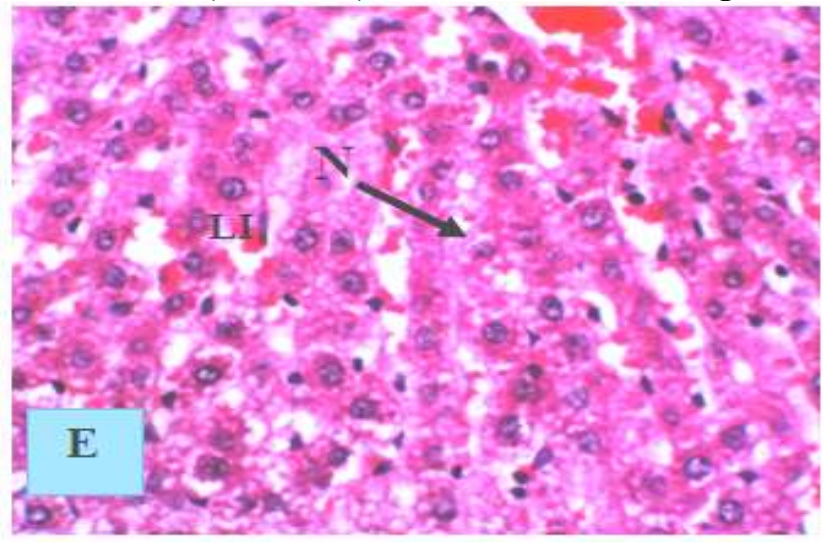

Fig. 2. E. Photomicrographs of histological section of liver group (G5) showing nearly normal hepatocytes but showing leukocyte infiltration . (H\&E .X400).

\section{Kidney:}

A comparative histopathological investigation of kidney of all groups are illustrated in Fig.3(A:E). Normal renal structure with controlled nuclear arrangement of uriniferous tubules and collecting tubules is observed. The renal corpuscles are formed of glomeruli $(G)$ and Bawman's Capsules. Renal tubules are lined by healthy epithelial cells around the lumina as shown in Fig. 3(A). 
The renal tubules appeared irregular, dilated, and atrophied of the glomerulus.

Fig. 3 (B) section of kidney positive group $(\mathrm{G} 2+\mathrm{ve})$ shows renal tubules with certain arranged collecting tubules. Degeneration of the lining epithelium of renal tubules with dilatation in renal tubules. Degeneration of renal corpuscles, degeneration of the lining of renal tubules. With abnormal swelling lumina, besides interstitial leukocyte infiltration were detected.

Treated group fed on biscuits addition of dried blueberries (G3) is shown in Fig. 3(C). The sections looked to be returning the normal appearance and evidence nearly normal renal structure including renal corpuscles and renal tubules. In Fig.3 (D and E),

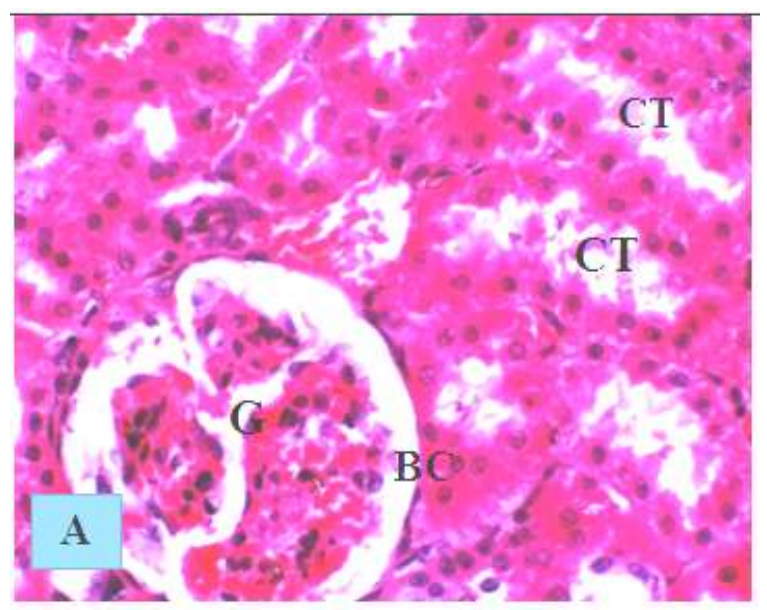

Fig. 3. A. Photomicrographs of histological section of Kidney control group (G1) showing normal renal structure including renal corpuscles and tube, normal glomeruli with characteristic endothelial cells and capsules having lining squamous endothelium, proximal and distal tubules lined with cuboidal epithelium and enclosed by tubular. BC, Bowmans capsule; CT, collecting tubule; G, glomeruli. (H\&E. X400).

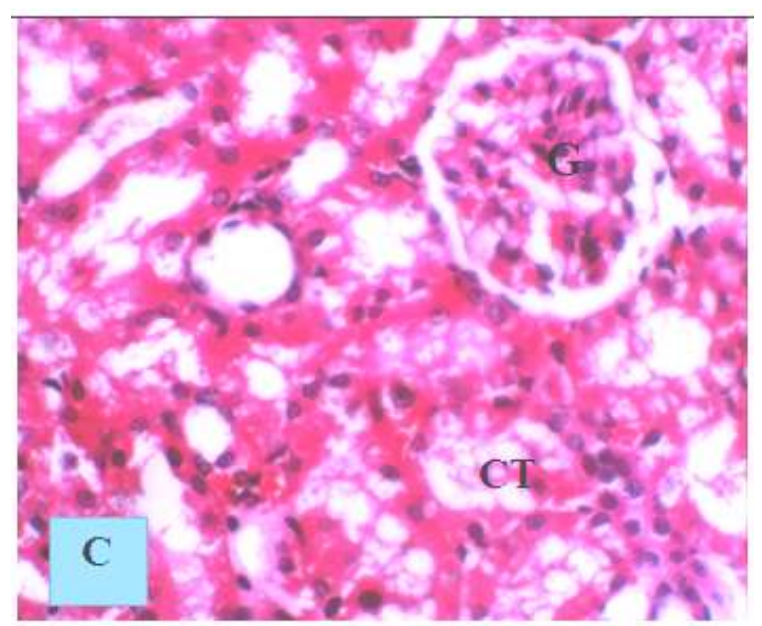

Fig. 3. C. Photomicrographs of histological section of Kidney of group (G3) showing nearly normal renal structure including renal corpuscles and tube. (H\&E. X400). treated groups fed on biscuits with wheat bran or nanocharcoal showed that distortion of renal corpuscles, exhibiting some degeneration of renal tubules, slight damage of epithelium lining the tubules and interstitial leukocyte infiltration are observed.

These findings were in parallel with those of (Nashwa et al., 2008) who told that the levels of serum urea and creatinine were significantly high in aflatoxicated groups as compared to healthy. This increase in concentrations in toxicated animals might be due to nephrotoxic action, which affects renal impairment by destruction of epithelial cells of proximal and distal convoluted tubules and alteration in tubular function.

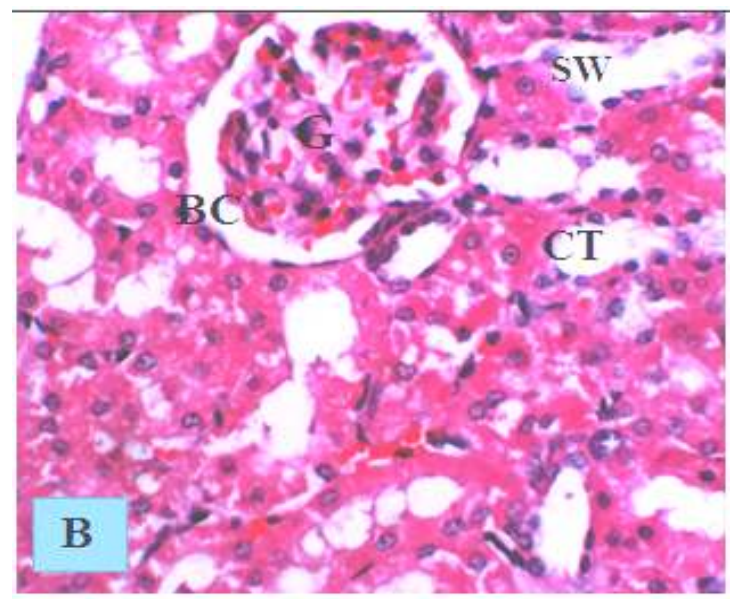

Fig. 3. B. Photomicrographs of histological section of Kidney positive group (G2) showing atrophied glomeruli with missing Bowman's space, and renal tubules with abnormal swelling lumina and damaged lining epithelium, and showing interstitial leukocyte infiltration. SW,swelling ,BC, Bowmans capsule ; CT,collecting tubule ; $\mathbf{G}$, grlomeruli. (H\&E. X400).

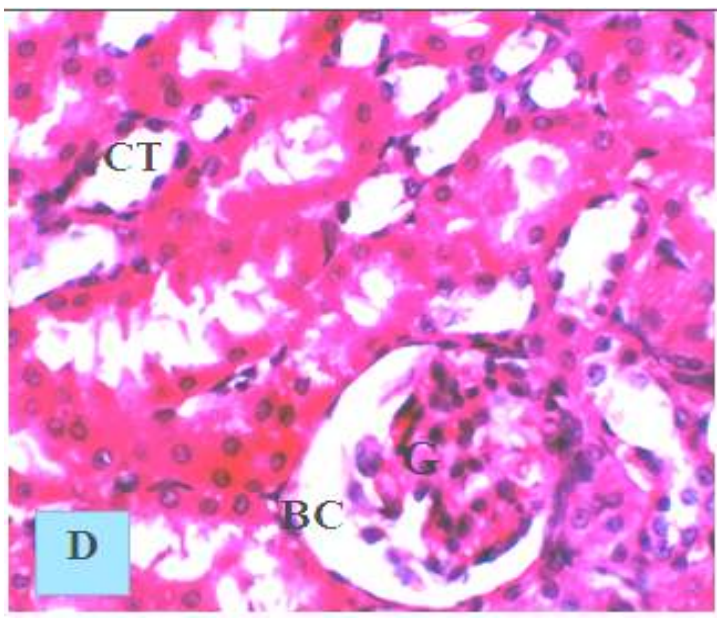

Fig. 3. D. Photomicrographs of histological section of Kidney of group (G4) showing slight damage of epithelium lining the tubules. (H\&E. X400). 


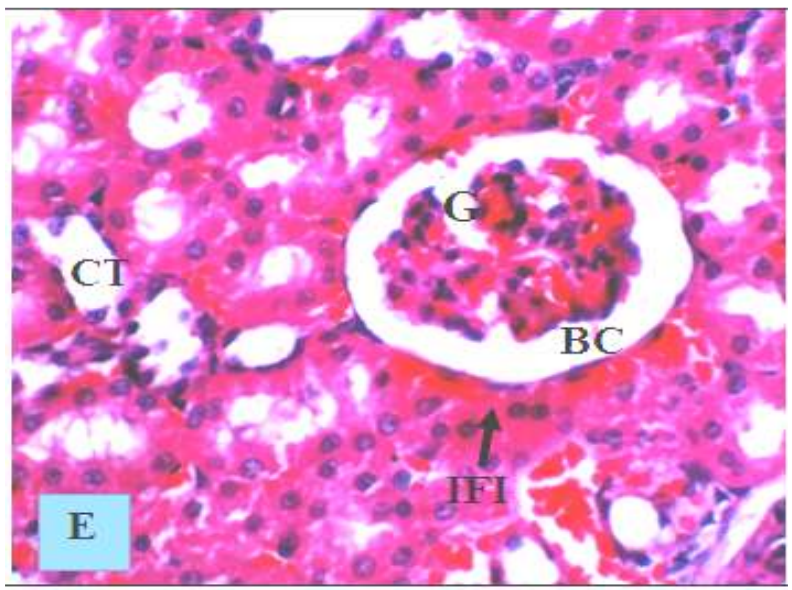

Fig. 3. E. Photomicrographs of histological section of Kidney of group (G5) showing slight damage of epithelium lining the tubules and interstitial leukocyte infiltration. (H\&E.X400).

\section{REFERENCES}

Abdelhamid, A. M. (1995). Rationalization of the optimum conditions for some mycotoxins separation by thin layer chromatography (TLC). J. Agric. Sci. Mansoura Univ., 20: 201-209.

Agag ,M.(2004).Mycotoxins in foods and feeds 1-aflatoxins Ass. Univ. Bull.Environ. Res. Vol. 7 No. 1.

Amir, C.; Hossein, K. and Mohammad, K. (2010). Optimized experimental design for natural clinoptilolite zeolite ball milling to produce nano powders. Powder Technol. 203: 389-396.

Bartles ,H.;Bohmer,M. and Heirlic.(1972).Creatinine in alkaline solution reacts with picric to form a colored complex. The amount of the complex formed is directly proportional to the creatinine concentration .Clin ., Chem., Acta,37,193,Clin. Chem.Acta,41,209.

Bowers, G. and Mc Comb, R. (1966). Acontinuous spectrophotometric method for measuring the activity of serum alkaline phosphatase .Clin.Chem., 12(2):7089.

Cheli,F. ; Pinotti, L. ; Rossi,L. and Dell 'Orto,V. (2013). Effect of milling procedures on mycotoxin distribution in wheat fractions : a review . LWT-Food Science Technology . 54:307 - 314.

Cynthia ,C.C;Ruth,L.K. and Barbra,J.B.(1993). Laboratory test and diagnostic procedures.W.R.Saunders Company.

Di Stefano, V.; Pitonzo, R. and Avellone, G .(2014) . Effect of gamma irradiation on aflatoxins and ochratoxin a reduction in almond samples. J Food Res 3:113-118.

Doumas, B.T.; Bayse, D.D.; Carter, R.J. ;Peters, T. Jr. and Schaffer ,R.(1981). A candidate reference method for determination of total protein in serum. I. Development and validation.Clin chem. 27(10): 1642-50.

Drury,R.;Wallington,E. and Cancerson,R.(1976). Carleton's histological technique ". $4^{\text {th }}$ ed .Oxford University Press, London.

Fossati,P. and Precipe,L. (1982).Serum triglycerides determined colorimeterically with an enzyme that produces hydrogen peroxide .Clin.Chem.,(28):20772080.
Guarisco, J.A. ; Hall, J.O. and Coulombe, R.A. Jr. (2007). Mechanisms of butylated hydroxytoluene chemoprevention of aflatoxicosis-inhibition of aflatoxin B(1) metabolism. Toxicol Appl Pharmacol 2008;227:339-46.

Hasheminya, M. and Dehghannya, J. (2013). An overview of genetically modified food products: Benefits, risks, health safety and related regulations, IRJABS. 4 (3), 724-727.

Jans, D.; Pedrosa, K.; Schatzmayr, D.; Bertin, G. and Grenier, B. (2014). Mycotoxin reduction in animal diets. In: Leslie JF, Logrieco AF (eds) Mycotoxin reduction in grain chains. Wiley, Oxford, pp. 101110.

Jimenez-Garcia ,S.N.; Guevara-Gonzalez, R.G.; MirandaLopez, R.;Feregrino-Perez, A.A.; Torres-Pacheco, I. and Vazquez-Cruz, M.A.(2012). Functional properties and quality characteristics of bioactive compounds in berries: biochemistry, biotechnology, and genomics. Food Res Int.

Jouany, J. P. (2007). Methods for preventing, decontaminating and minimizing the toxicity of mycotoxins in feeds. Anim. Feed. Sci. Technol. 137, 342-362.

Kamkar, A.; Yazdankhah, S.; Mohammadi Nafchi, A. and MozaffariNejad, A.S. (2013).Aflatoxin M1 in raw cow and buffalo milk in Shush city of Iran. Food Add Contamin: Part B.

Kannewischer, I.; Arvide ,M.T.; White ,G.N. and Dixon, J.B.(2006). Smectite clays as adsorbents of aflatoxin B1: initial steps. Clay Sci 2006, 2:199-204.

Kaplan,A. and Teng ,L.L. (1982). In Selected Methods of Clinical Chemistry, By W.R.Faulkner and S.Meites, AACC, Washington. (9):357-363

Kittinaovarat, S.; Suthamnoi, W. (2009). Physical properties of polyolefin/bamboo charcoal composites. J. Met. Mater. Miner.19: 9-15.

Kumar, R.; Mishra, A.K.; Dubey, N.K. and Tripathi, Y.B.(2007). Evaluation of Chenopodium ambrosioides oil as a potential source of antifungal, antiaflatoxigenic and antioxidant activity. Int. J. Food Microbiol. 115, 159. 
Lashmanova, K.A.;Kuzivanova ,O.A. and Dymova, O.V.(2012). Northern berries as a source of carotenoids. Acta Biochim Polinica. 59(1):133-134 .

Lopez-Virella,M.F.(1977).High density lipoprotein cholesterol by selective precipitation .Clin. Chem. 23(5):882-884.

Madrigal-Santiallan; Morales-Gonzalez, J.; VargasMendoza, N.; Reyes Ramirez, P. and Cruz-Jaime, S. et al., (2010). Antigenotoxic studies of different substances to reduce the DNA damage induced by aflatoxin B1 and ochratoxin A. Toxins, 2:738-757.

Mahmoud, K. I.; Abdelhamid, A. M. and Mandour, A. (1994). In vitroand in vivo comparative studies on the efficacy of some aflatoxin-detoxifying agents. Alex. J. Vet. Science, 10: 39-47.

Mogda K. Mansour; Amany Y. Nahed, M. El-Mokhtar and Seham ,F. El-Hadad .(2015).Protective effect of some antioxidant compound on albino rats intoxicated with aflatoxin Egypt. J. Chem. Environ. Health, 1 (1):7993.

Nashwa, A. Abu-Aita; Mogda K. Mansour, Samer, M. Moneir and A.A. Nada (2008). Influence of the probiotic pediococcus acidilactici on chromosomal aberrations, clininicopathological alterations and immunological changes in aflatoxicated rabbits. Vet. Med. J., Giza. Vol. 56.

Ostry, V.; Malir, F.; Toman, J. and Grosse, Y. (2017). Mycotoxins as human carcinogensdthe IARC Monographs classification. Mycotoxin Research, 33(1), 65-73.

Pál, L.; Dublecz, K.; Weber, M.; Balogh, K.; Erdélyi, M.; Szigeti, G. and Mézes, M. (2009). Effect of combined treatment with aflatoxin B1 and $\mathrm{T}-2$ toxin and metabolites on some production traits and lipid peroxide status parameters of broiler chicken. Acta Vet. Hung. 57, 75-84.

Ramos, A. J.; Fink-Gremmels, J. and Hernandez, E. (1996). Prevention of toxic effects of mycotoxins by means of non-nutritive adsorbent compounds. J. Food Prot. 59, 631-641

Reddy, K.R.; Reddy, C.S. and Muralidharan, K. (2009). Detection of Aspergillus spp.And aflatoxin B1 in rice in India. Food Microbiology .26: 27-31.
Reitman, S. and Frankel, S.A. (1957): Colorimetric method for determination of serum glutamic oxaloacetic and glutamic pyruvic transaminases. Am J Clin Path. 28:56-63.

Sahin , T. and A sehu.(2007). Effects of hydrated sodium cacium aluminosilicate (HSCAS) on aflatoxicosis in broilers . Arch .Geflu., 71(2).S.88-92.ISSN00039098.

SAS Institute (2006) .SASATAT User's Guide . Release 9.1. SAS Inst. Inc.,Cary, NC.

Shabani, B.; Dasta-Khomeiri,M. ; Shabanpour,B. and Hassani,S.(2010).Re-sponse of broiler chickenst different levels of nanozeolite during experimental aflatoxicosis .J.Biol.Sci.(10):362-367.

Sherif, S.O.; Salama, E.E. and Abdel-Wahhab, M.A. (2009): Mycotoxins and child health: the need for health risk assessment. (Review) Int. J. Hyg. Environ. Health, 212: 347368 .

Stanley,V.G.; Winsman,M.; Dunckley,C.; Daley,M.; kruger,W.F.; Sefton , A.E. and Hinton , A.(2004). Impact of yeast culture residue on the supplementation of dietary aflatoxin in performance of broiler breeder hens. J.Appl.Poult.Res., 13:533-539.

Subramaniam, S.; Khan, H.B.H.; Elumalai, N. and Lakshmi , S.Y.S.(2015).Hepatoprotective effect of ethanolic extract of whole plant of Andrographis paniculata against CCl4-induced hepatotoxicity in rats. Comp Clin Path .24:1-7.

Szajdek ,A. and Borowska, E.J.(2008). Bioactive compounds and health promoting properties of berry fruits: a review. Plant Foods Hum Nutr 63:147-156.

Teuscher, A. and Richterich, P. ( 1971) . Schweiz Med. Wschr., 101:345-390.

Tietz,N.W.(1986) . Text Book of Clinical Chemistry . P.796.Saunders,W.B.Co., London-Pheladelphia.

Wacoo, A.P.; Wendiro, D.;Vuzi ,P.C. and Hawumba, J.F. (2014).Methods for Detection of Aflatoxins in Agricultural Food Crops. J. appl. chem. 11-15.

Weissman, N.; Schoenbach, E.B. and Armestead, E.B. (1950). The determination of sulfhydryl groups in serum. I. Methods and results on normal sera. J. biol. chem., 187:153.

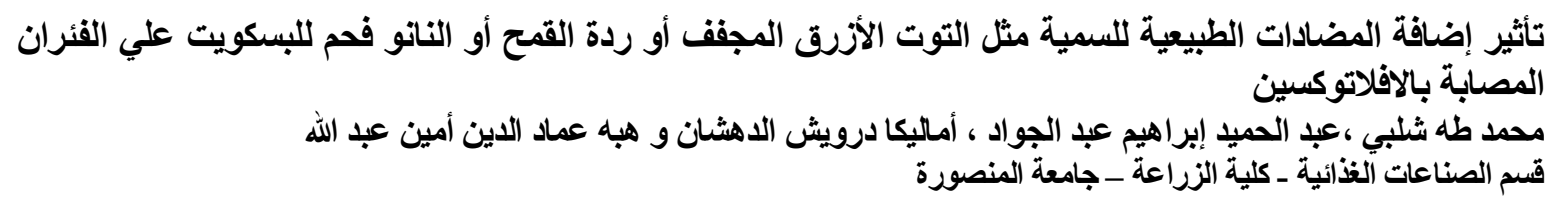

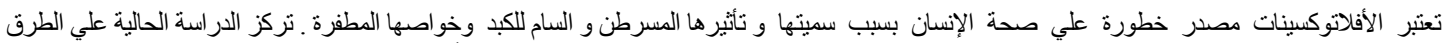

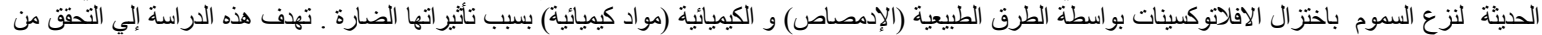

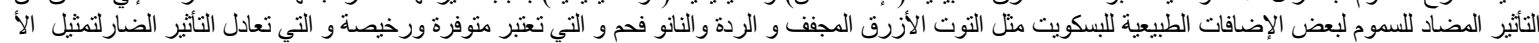

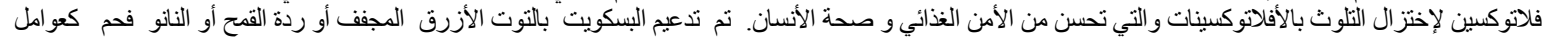

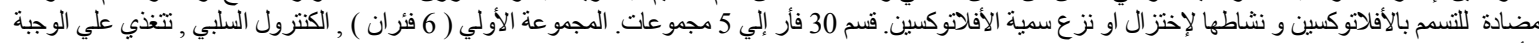

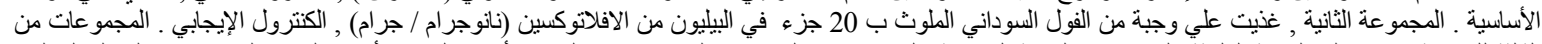

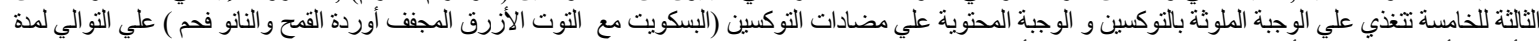

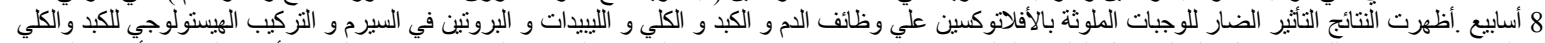

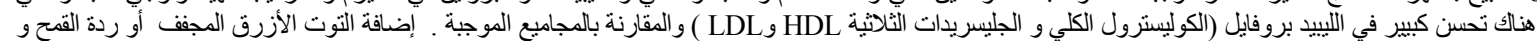

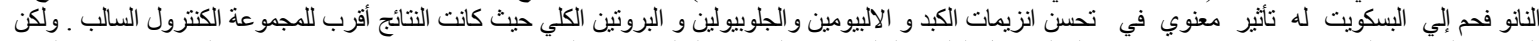

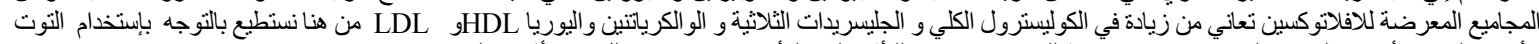

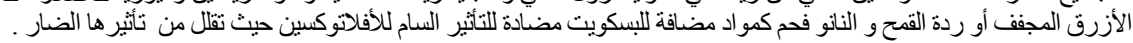

